\title{
GROWING STUDENT VOICE IN CURRICULUM DECISIONS AT THE UNIVERSITY
}

\author{
Susana Rojas Pernia, Ignacio Haya Salmón and Teresa Susinos Rada \\ University of Cantabria
}

Key words: Student voice, higher education, curriculum, inclusion.

This paper is a result of the development of the $\mathrm{R}+\mathrm{D}$ Project Schools that are moving towards inclusive education: working with the local community, the student voice and educational support for promoting change in conjunction with the Innovation Project Building Bridges. An Educational Innovation Project in the European Higher Education Area which has been developed in the University of Cantabria (Spain). The main objective of this project is to put into practice teaching methodology which reflects the inclusive principle of collaboration, with the aim of widening student participation as agents in the development of the curriculum (Seale, 2010). The initiative is being developed over two academic years 2013/14 and 2014/15 in two subjects in Primary Education teacher training. One hundred and eighty-six students together with their teachers are taking part in the project. The project has been organised in two phases. In the first phase, students from the two participating groups chose different materials and resources for teaching three major topics in schools: collaboration, the feeling of belonging and respect for differences. In the second phase, some of the students from both subjects, together with their University teachers, established a Resource Guide which could be considered as one of the main results of this project. Furthermore, the latter required sustained commitment over time (8 months). Similarly other collaborative values, which will be discussed in further detail, can be found in this work. These are: the connection between training and the real needs of schools (Zeichner, 2010), the projection of work carried out towards the future given that this will be shared with students from subsequent courses or the proposal of collaboration with the material and tangible objective of practical use aimed at inclusive education. Lastly, the project has been evaluated by the participants based on in-depth interviews. In this summary, it can be seen that students have emphasised the value of this project as a way of enabling them to experience new teaching methodologies which promote a realistic connection between what is studied in the classroom with actual practice in schools.

\section{Introduction}

This paper is the result of the joint development of two projects: the first being 'Schools that are moving towards inclusive education: working with the local community, the student voice and educational support for promoting change', an $\mathrm{R}+\mathrm{D}+\mathrm{i}$ Project; and the second 'Building bridges. An Educational innovation project in the European Higher Education Space', approved in the University of Cantabria's 2nd Call for Innovation in Teaching.

We here describe the innovation experience in which various lecturers and final-year Education Degree students participate. Based on a common and shared project - the creation of a resource guide for developing inclusion in primary schools - we focus on fundamental questions such as respecting differences or the sense of belonging to the community. Furthermore, we reflect upon our role as teachers and trainers and the importance of listening to and incorporating student voice into the curriculum.

As we describe below, the process we followed proved to be beneficial for all parties, allowing us to explore other possibilities in the training processes and in the learning environments. In the words of some of the participating students, 'we discovered that what was important was not the product we sought to create, i.e., the Guide, but more so the path we walked along in to reach our aim. Because in this process not only did we question education and how we constructed it but also rather ourselves, our approach' (Oniboni, Villahoz, Fernández, et al., 2014: 663).

In this paper, we wish to share the experience carried out during two university years, 2013/14 and 2014/15. Therefore, we will first attempt to briefly place the experience in its context (phases, proposals and participants) and we will describe some of the ideas on which it is based. Later, we will present the 'Resource guide: advancing towards educational inclusion' (Rojas and Haya, 2014). This is a tool designed with the aim to facilitate the way undergraduates think and work in schools. Lastly, we collect some of the assessments that the students made on the innovation experience and their participation in the project. 


\section{Our experience: Building bridges}

The experience we present here covers, as we explained above, two academic years. Five teachers and 186 students from two subjects: 'Inclusive schools' and 'Inclusive classrooms and schools' - from the final year of the Degree in Education. Both subjects represented a broadening of the set of knowledge, skills and attitudes worked upon in previous years, specifically in the subject Theoretical Basis on at school System on Diversity at school system.

The process carried out (see Figure 1) allows us to identify three interconnected phases, in which each one is recognised as having a marked collaborative reflective nature. From the outset, students from each of the subjects worked in the classroom during 4 months on one of the three topics which were proposed as being relevant in our respective subjects: collaboration, sense of belonging and respecting differences.

Later, on completion of the subject, some students and lecturers worked jointly for 8 months on the development of training material. Thus, the project initially created in the two classrooms with two lecturers passes from that designed in controlled teaching spaces to become an activity that brings together a more reduced group of students and some lecturers. The aim was to build new bridges' between schools and final-year degree students. The creation of a Resource Guide for developing more inclusive practices in schools was proposed. During the 2014/15 academic year, the material was checked and assessed by the students from these subjects and was distributed among schools.

Novoa and Bolívar (2015), in a recent research study devoted to new epistemological teaching stated that if we wish to change the roles that people perform in an organisation, instead of preaching to change beliefs, it is preferable to create structures and contexts that support, promote and strengthen the teaching practices we wish to have' (p. 17). In this sense, three ideas shaped the experience and became a constant during the whole work process, helping us not only to change the usual ways of acting but also certain opinions: (1) the student as the

Figure 1: Phases of the innovation experience

Phases of the Innovation Project "Building Bridges":

PHASE 1. Work in two classes. Two teachers in charge working together.

- Common Project:

- Preparation of class-group work: search for resources and design of activities for the development of inclusive practices in Pre-primary and Primary Education.

- Collaborative preparation of the materials that will give the final shape to the subject.

- Development: work in a class-group, small groups or seminars.

- Assessment:

- Assessment process training by means of weekly reports.

- Global evaluation in small groups and whole class.

- Duration: September 2013-January 2014

PHASE 2. Intensive work group comprising 5 teachers and 5 students.

- Common Project:

- "Resource Guide: advancing towards educational inclusion" in Education

Degree.

- Development: by means of work seminars

- Assessment: Joint final assessment

- Duration: March 2014 - October 2014

PHASE 3. Two class-groups and two teachers in charge. These teachers and 5 students from previous years working together.

- Common Project:

- Assessing and broadening of "Resource Guide: advancing towards educational inclusion" in Education Degree.

- Development: by means of work in a class-group, small groups and seminars.

- Assessment: assessment training process. By means of weekly reports.

- Global assessment in small groups and in class-group.

- Duration: October 2014-January 2015

More information: Interviews and other data (work carried out by the students). 
leading actor in their learning process; (2) collaboration as a training tool; and (3) experience, know-how and commitment to a democratic school. We will refer to these three ideas briefly below.

The innovation experience allows us to create a space in which students played a lead role and in which we established a process of constant dialogue supported outside the classroom space. We discussed the analysis of the material and resources in small seminars, work meetings and meetings between the students themselves. This allowed us to incorporate contents and ways of acting that the students defined as valuable. As we pointed out in other work (Rojas, Haya and Lázaro-Visa, 2011; Susinos and Rodríguez-Hoyos, 2011), we need space and time for the negotiation of concepts, upon which we can then reflect (namely, diversity, respect, difference, improvement or voice). We also question the categorical organisation of the world and reflect upon its dominant discourses on 'Others' or on diversity and our role as educators. The relationships are based on mutual trust, care and respect for others (Fielding, 2011).

Therefore, another important idea deals with collaboration as a value upon which to build bridges: between the fellow students in a class group, between two classes from two academic years, between students and teaching staff, and between the University and the School. Moreover, during the time the subjects lasted, the students prepared together with the lecturer the classroom material and therefore confirmed, added to and asked about the contents of the subject. They were working on different activities with classmates with whom they had not worked previously.

This led us to the final idea, the need to think about what we have lived and understand that know-how, as Contreras and Pérez de Lara (2010) point out, is not a saleable good, but something that must remain as very much part of us. The definition of a common and shared project the creation of a set of materials that can support us in the development of systems that are more inclusive checked on a weekly basis, analysed by teachers and fellow students in the classroom, depicts a process that is difficult to conceive without involvement and commitment on the part of those who participate.

The work initiated in the two classrooms was later continued by a group of teachers and students, creating a tool for the training of future teachers and which would serve as support for professionals in schools (Phase 2).

\section{Drawing up a Resource Guide for advancing towards educational inclusion}

The importance of the path: the preparation process Just as we compile in the 'Resource Guide' (Rojas and Haya, 2014), this material 'arose from a result of pooling together information, discussion, the search joint reflection shared personal experience, dialogue and the collective dream to create material that can benefit other people by thinking about its contents' (p. 8). The preparation process refers to the work that we carried out jointly over months as a group of people linked to the university and to the project of a better school for all, with differing personal and professional histories. Student adherence to the project was voluntary, after the teachers had made an open invitation to all the students who had participated in the subjects the project lies within.

From this moment onwards, the main challenge the new team faces resides on two major tasks:

- First, reflecting upon the sense and value that the work acquires for schools in each of the areas examined in this guide, recovering the proposals that we have drawn up in the first phase of the project. The complexity of this task lies in recovering the contributions made by the different groups of students, the proposals that promote a notion of school ethos close to the ideal of an inclusive school.

- Second, selecting the resources that best adapt to what the preparation of the material means to us and proposing other new resources.

\section{The guide as a product}

The material we produced recognises the complexity of the teaching activity and the idiosyncrasy of each school, so that it will be of different use depending on different school contexts and the possibilities that each teacher finds in the Guide. Our interest in making the teachers' task easier in the school improvement process encouraged us to give the guide a structure and contents that promoted a high degree of interactivity among its potential users, ensuring that it would be user-friendly from a formal standpoint.

Far from being a mere list of resources, the guide is structured along three thematic lines that give sense to the way we present the resources. These lines are: respect for differences, collaboration and the sense of belonging (Figure 2). Each block of resources is preceded by an analysis of each of the constructs, in which the work team synthesises the meaning each of them acquires for a school that seeks to become a place where each child feels respected and where they can feel what it is like when others value what they are capable of doing, teaching and learning from and with others.

Each of the three sections, which we might consider as being a space for reflection that theoretically gives support to each of the areas examined in the Guide, is accompanied by a more practical proposal of several resources (cartoons, activities, films, games or songs). Each of these resources is described and briefly referenced, with contents that can be worked on in Primary 
Figure 2: List of contents and resources in the guide

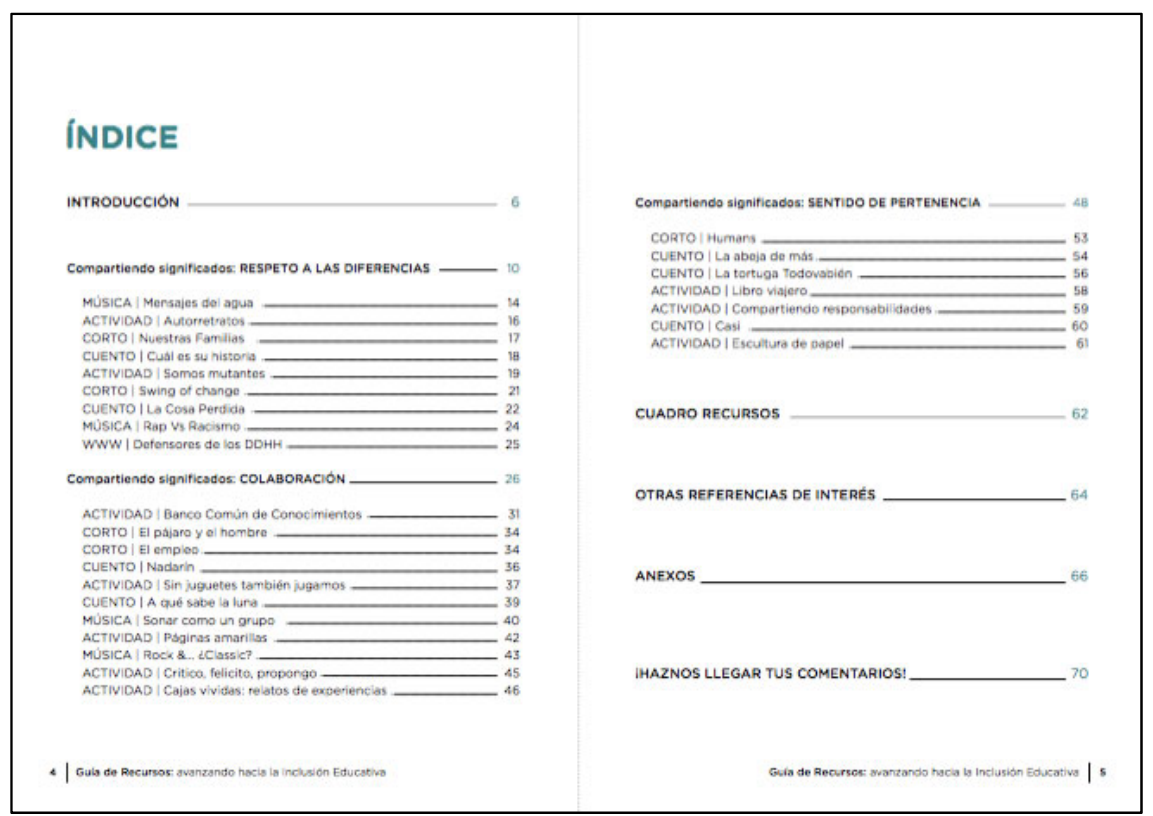

Education along with a suggestion on how to proceed (Figure 3). The resources in question explore different channels, media and language such as written texts, images, activities and dynamics or audio-visual material. Nevertheless, in no case does the previous idea means that there are inflexible guidelines as to the use of the guide or an established order in the use of the resources. In short, the guide seeks to become the appropriate 'pretext' in order to continue dreaming up and looking for, from each of the specific and complex contexts that schools are, ways to accomplish this right to a quality education for all.

\section{Using the words of our students}

We started this paper pointing out that the most important element of the innovation experience had been - for both teachers and students alike - the path we had laid down together. This journey 'gave us the opportunity to participate in a project that sought not simply to offer theoretical learning, and one to a certain extent far from the meaning of the words "collaboration" and "participation," but more one that would lead us to experience the value of an inclusive education as the project developed' (2013/ 14 student). Without stressing the difficulties arising from a more individualistic way of acting, 'the collaborative nature of the project created certain interdependence between the other groups' (2013/14 student) and also with the teaching staff. In this sense, an essential aspect of the experience has been 'the horizontal meeting between students and teachers (...) that recognises that students also have knowledge to offer' (2013/14 student).

Precisely, it is this degree of participation that has made it easier for the students to get a closer appreciation of new ways of understanding the teaching profession. They have become linked to with the commitment and responsibility that is required from forming part of a profession in which one can and must share points of view, questions and reflections on the tasks proposed that belong to a common goal. In their own words, "the project has led us to conceive the role of the teacher from a perspective closer to a professional who analyse themselves and their

\section{Figure 3: Guide resource}

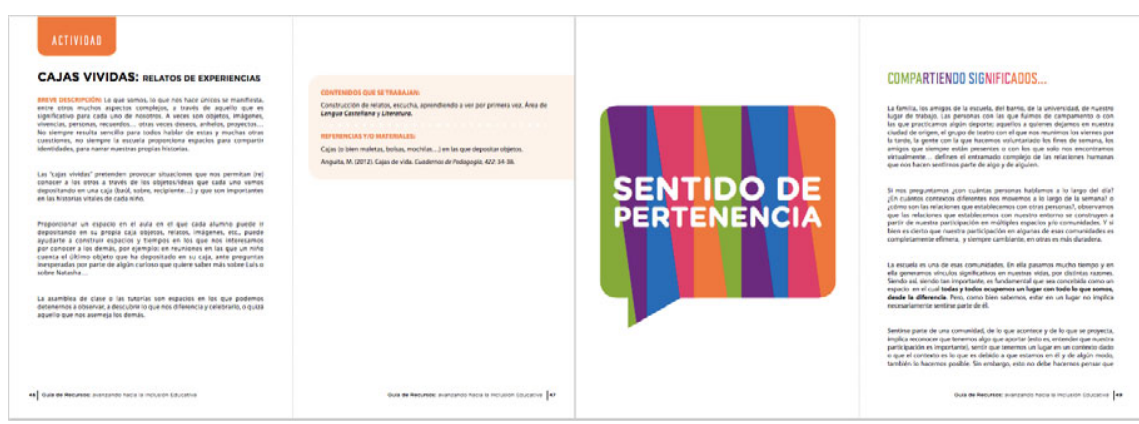


own practices. It has made us assume that we are in constant evolution (...) the idea of constantly improving our practice spurs us on to care so much more for what we do’ (2014/15 female students).

The material presented is the result of the spaces of reflection and debate that have been developed over months between the teaching staff and students involved. Consistent with the arguments of certain authors (Hamilton Jones, 2013; Zeichner, 2010), the University must introduce changes in the programmes that promote the development of collaboration as a training tool. For this to occur, it is necessary for the institution to recognise and value the experiences that permit future teachers to participate in their training process, without forgetting that the said institution must accompany them in the possibility for change, 'that there are other ways to act and be', 'because our responsibility is to discover, to perceive possibilities' (2013/14 student).

\section{Conflicts of interest}

The author declare no conflict of interest.

Address for correspondence

Susana Rojas Pernia

Faculty of Education

Avda. de los Castros s/n

39005. Santander. Cantabria (Spain)

E-mail: rojass@unican.es

\section{References}

Contreras, J. \& Pérez de Lara, N. (2010) Investigar la experiencia educativa. Madrid: Morata.

Fielding, M. (2011) 'La voz del alumnado y la inclusión educativa: una aproximación democrática radical para el aprendizaje intergeneracional.' Revista

Interuniversitaria de Formación del Profesorado, 70 (25), pp. 31-61.

Hamilton Jones, B. (2013) 'Preparing special educators for collaboration in the classroom: preservice teachers' beliefs and perspectives.' International Journal of Special Education, 28 (1), pp. 56-68.

Novoa, A. \& Bolívar, A. (2015) 'Presentación. Nuevas epistemologías docentes.' Revista de Docencia Universitaria, 13 (1), pp. 17-9.

Oniboni, A., Villahoz, R., Fernández, A., Quintanal, C. \& del Castillo, F. (2014) Proceso de elaboración de una Guía de Recursos para escuelas inclusivas a partir de la colaboración entre alumnos y docentes de la Facultad de Educación de la Universidad de Cantabria. XIII Congreso Internacional de Formación del Profesorado. Investigar para acompañar el cambio educativo y social. El papel de la Universidad (652667). Santander: Universidad de Cantabria.

Rojas, S. \& Haya, I. (coord.) (2014) Guía de recursos: avanzando hacia la inclusión educativa. Santander: Universidad de Cantabria.

Rojas, S., Haya, I. \& Lázaro-Visa, S. (2011) 'La voz del alumnado en la mejora escolar: niños y niñas como investigadores en educación primaria.' Revista de Educación, 359, pp. 81-101.

Seale, J. (2010) 'Doing student voice work in higher education: an exploration of the value of participatory methods.' British Educational Research Journal, 36, pp. 995-1015.

Susinos, T. \& Rodríguez-Hoyos, C. (2011) 'La educación inclusiva hoy. Reconocer al otro y crear comunidad a través del diálogo y la participación.' Revista Interuniversitaria de Formación del Profesorado, 70 (25), pp. 15-30.

Zeichner, K. M. (2010) La formación del profesorado y la lucha por la justicia social. Madrid: Morata. 